\title{
The Extra-territorial Application of Hong Kong Security Law on Data Stored Overseas: a preliminary conflict-of-laws analysis
}

\author{
Jie (Jeanne) Huang \\ Associate Professor, University of Sydney Law School
}

\section{Extract:}

Internet intermediaries and content providers should be alert to the extra-territorial application of Hong Kong Security Law on data stored overseas. This preliminary conflictof-laws analysis tries to explore the extra-territorial application of Hong Kong Security Law from two aspects. First, whether Hong Kong authorities can request data about Hong Kong users if it is stored overseas. Second, whether an overseas social media user could see their posts removed at the request of Hong Kong authorities.

Hong Kong is one of the important global locations for data centres, including cloud and content providers, due to its stable electricity supply, relatively low risk for natural disasters, and the proximity to Mainland China. According to the Hong Kong Data Centre Market Report 2019, "Hong Kong has shifted from seeing growth in the financial services, securities, and insurance verticals to growth driven by large-scale cloud and content providers. While data centre construction was initially led by financial service and IT companies, it is now the large global multimedia companies that will drive data centre construction over the next five years."

The Law of the People's Republic of China on Safeguarding National Security in the Hong Kong Special Administrative Region ('Hong Kong Security Law') was enacted and came into force on 30 June $2020 .^{2}$ The law is legislated according to Article 23 of the Hong Kong Basic Law under the 'One Country, Two Systems'. This Law has spurred significant international disturbance and debates. ${ }^{3}$ A critical question is whether this Law will be extraterritorially applied to data stored overseas. This preliminary conflict-of-laws analysis tries to answer this question from two parts. First, whether Hong Kong authorities can request data about Hong Kong users if it is stored overseas. Second, whether an overseas social media user could see their posts removed at the request of Hong Kong authorities.

\section{Can Hong Kong authorities request data about Hong Kong users if it is stored overseas, how much leeway will companies have to push back against government requests to take down or hand over data?}

1.1. If a data company is registered in Hong Kong, Chinese or Hong Kong government can compel it to hand over data via two channels:

\footnotetext{
${ }^{1}$ Hong Kong Data Centre Market Report 2019, https://www.businesswire.com/news/home/20191016005767/en/Hong-Kong-Data-Centre-Market-Report-2019.

2 The Law of the People's Republic of China on Safeguarding National Security in the Hong Kong Special Administrative Region (hereinafter 'Hong Kong Security Law'), enacted at the $20^{\text {th }}$ Meeting of the Standing Committee of the $13^{\text {th }}$ National People's Congress on 30 June 2020.

${ }^{3}$ E.g. Chinese Parliament Approves Controversial Hong Kong Security Law, https://www.theguardian.com/world/2020/may/28/china-vote-npc-national-security-laws-hong-kong-us-protest.
} 
The first channel is through the Committee for safeguarding National Security and the department for safeguarding national security of the Police Force of the Hong Kong Special Administrative Region. ${ }^{4}$ The police have to prove a data company is suspected, on reasonable grounds, to have possession information or material to investigation of an offence under Article 43 of the Hong Kong Security Law. ${ }^{5}$ Here Hong Kong court should hear the case and apply Hong Kong law.

The second channel is through the Office for Safeguarding National Security of the Central People's Government (hereinafter 'the Office'). The Office may not need to prove a reasonable ground of suspicion before compelling a data company to hand over data. This is for three reasons. First, Article 59 of the Hong Kong Security Law provides that in a case over which jurisdiction is exercised pursuant to Article 55 of this Law, any person who has information pertaining to an offence endangering national security under this Law is obliged to testify truthfully. Article 59 differs from Article 43 and contains no wording similar to 'reasonable grounds'. Second, Article 57 of the Hong Kong Security Law provides that the Criminal Procedure Law of the People's Republic China and other related national laws shall apply to procedural matters including those related to criminal investigation in respect of cases over which jurisdiction is exercised by the Office. Namely, Article 57 allows the application of Mainland Chinese law to activities allegedly violating Hong Kong Security Law. Article 56 of the Hong Kong Security Law provides potentials for Mainland courts to exercise jurisdiction because it states that the Supreme People's Court shall designate a court to adjudicate violations. Mainland Chinese law does not explicitly require the government authority to prove 'reasonable grounds' before requesting data about Hong Kong users if it is stored overseas. For example, Article 18 of Chinese National Security Law does not require a government agency to prove 'reasonable grounds' before compelling a data company to surrender data. Article 11 of the same Law provides that National security organs may inspect equipment and facilities such as to maintain organizations and personal communication tools, devices, and equipment.

1.2. If a data company is not registered in Hong Kong, Hong Kong government may invoke judicial assistance treaties that Hong Kong concluded to request data stored overseas. For example, Australia enacted the Mutual Assistance in Criminal Matters (Hong Kong) Regulations in 1999 ('Australia-Hong Kong Mutual Assistance Regulations') according to an agreement with Hong Kong. ${ }^{6}$ This Regulations provide for mutual assistance in the investigation and prosecution of criminal offences. ${ }^{7}$ Assistance includes providing information, documents and records. ${ }^{8}$ The assistance request should be submitted through Australia central authority being the Attorney-General's Department. Australia can refuse to provide access to data held in Australia on any of the following grounds: the request for assistance impairs its sovereignty, security, or public order of Australia, the request relates to an offence of a political character or will result in a person being prejudiced due to his or her political opinions, granting the request would seriously impair essential interests of Australia,

\footnotetext{
${ }^{4}$ Arts $12,15,16,18$, and 19 of the Hong Kong Security Law.

${ }^{5}$ Art. 43 of the Hong Kong Security Law provides that the police can search of premises, vehicles, vessels, aircraft and other relevant places and electronic devices that may contain evidence of an offence; and require a person, who is suspected, on reasonable grounds, of having in possession information or material relevant to investigation, to answer questions and furnish such information or produce such material.

${ }^{6}$ Agreement between the Government of Australia and the Government of Hong Kong concerning Mutual Legal Assistance in Criminal Matters.

${ }^{7}$ Art I (1) of Mutual Assistance in Criminal Matters (Hong Kong) Regulations 1999 made under the Mutual Assistance in Criminal Matters Act 1987.

${ }^{8}$ Ibid., Art I (2)(i).
} 
or the acts or omissions alleged to constitute the offence would not have constituted an offence in Australia. ${ }^{9}$

Therefore, it is unlikely that Australia will provide judicial assistance to Hong Kong government to access data stored in Australia to investigate or prosecute offences under the Hong Kong Security Law.

1.3. If the data is financial data stored in Australia by an Australian company, Hong Kong financial regulatory authority may invoke the Hong Kong-Australia Free Trade Agreement ('FTA') to access such data.

Regarding financial data, Australian data centres should be alert to Paragraph 2 of Article 11.15 of the Australia-Hong Kong FTA. ${ }^{10}$ This Article provides that '[n]either Party shall require a covered financial person to use or locate computing facilities in the Area of the Party as a condition for conducting business in that Area, provided that the Party's financial regulatory authorities, for regulatory and supervisory purposes, have immediate, direct, complete and ongoing access to information processed or stored on computing facilities that the covered financial person uses or locates outside the Area of the Party.' (emphasis added).

Firstly, it is unclear whether the regulatory and supervisory purposes include preventing and combating national security violation. Arguably, Australian government should insist on a narrow definition and exclude national security violations from the scope of Para 2 of Article 11.15 .

Secondly, this provision only applies to computer servers and storage devices for the processing or storage of information for the conduct of business according to Article 11.14 of the Australia-Hong Kong FTA. ${ }^{11}$ Here 'business' should be limited to financial services, because Article 11.14 is in Section B titled 'Movement of Information and Location of Computing Facilities for Financial Services'. It does not include computer servers or storage devices of or used to access:

(a) financial market infrastructures;

(b) exchanges or markets for securities or for derivatives such as futures, options and swaps; or

(c) non-governmental bodies that exercise regulatory or supervisory authority over financial services suppliers;

Thirdly, Australian government may refuse to provide access to financial data processed in Australia to the Hong Kong financial regulatory authority for legitimate public policy objective. ${ }^{12}$ Australia government may need to clarify whether supporting democratic movement in Hong Kong is a legitimate public policy objective in Australia so as to provide certainty to Australia data centers and financial institutions who do business with Hong Kong.

\footnotetext{
${ }^{9}$ Ibid., Art. IV.

10 The Australia-Hong Kong FTA entered into force on 17 January 2020, https://www.dfat.gov.au/trade/agreements/in-force/a-hkfta/Pages/default.

${ }^{11}$ Art. 11.14 of the Australia-Hong Kong FTA.

${ }^{12}$ Para 5 of art. 11.14 of the Australia-Hong Kong FTA.
} 


\section{Could an overseas social media user see their posts removed at the request of Hong Kong authorities (given Article 38 of the Hong Kong Security Law) if they are considered a national security crime?}

Article 38 of the Hong Kong Security Law provides that this Law shall apply to offences under this Law committed against the Hong Kong Special Administrative Region from outside the Region by a person who is not a permanent resident of the Region. If this person is not physically in Hong Kong and has no asset there, although Hong Kong courts can exercise personal jurisdiction on this person based on Article 38, this person may disregard the relevant sentencing.

Nevertheless, the teeth of Article 38 is on Internet intermediaries rather than the individual content provider (i.e. social media users). Two issues are involved.

First, whether Hong Kong courts can issue a global injunction on an intermediary to remove or de-reference contents allegedly violating Hong Kong Security Law. If an internet intermediary is registered in Hong Kong, according to Articles 37 and 43 of the Hong Kong Security Law, it has to comply with the Hong Kong judgment and remove/de-reference the posts. However, the key question is whether the Hong Kong Security Law requires a global removal or de-referencing. The Hong Kong Security Law is unclear on this issue. A comparative case is the European Court of Justice judgment on whether Google must apply removal to all its search engine's domain name extensions when requested from a natural person for links to web pages to be removed from the list of results displayed following a search conducted on the basis of that person's name. ${ }^{13}$ The European Court of Justice holds that there is no obligation under EU law, for a search engine operator who grants a request for de-referencing made by a data subject following an injunction from a supervisory or judicial authority of an EU Member State, to carry out such a de-referencing on all the versions of its search engine. ${ }^{14}$ Such a de-referencing request is limited to the versions of its search engine corresponding to all the Member States. ${ }^{15}$ An important reason for the Court's decision is that 'numerous third States do not recognise the right to de- referencing or have a different approach to that right.' ${ }^{16}$ Essentially, the Court considers it should respect that other states likely exercise different balance between the right to privacy and the freedom of information of internet users. ${ }^{17}$ Advisably, Hong Kong courts should acknowledge that the concept of national security and the level of censorship vary significantly state to state. Thus far, even Chinese courts have never rendered a global injunction on online contents violating Chinese National Security Law. Therefore, Hong Kong courts should refrain from issuing a global injunction on contents allegedly violating Hong Kong Security Law. Nevertheless, Hong Kong courts may require the intermediary to take measures which effectively prevent or seriously discourage an internet user from Hong Kong and Mainland China to access the contents allegedly violating the Hong Kong Security Law.

The second issue is, when the Internet intermediary is registered overseas, whether Hong Kong judgment on national security violation can be recognized and enforced in the state where the intermediary is registered. This issue is important for the Hong Kong authority because if a foreign intermediary has no asset in Hong Kong, it may disregard the judgment. Therefore, cross-border judgment recognition and enforcement is critical. Notably, in

${ }^{13}$ Google LLC, successor in law to Google Inc. v Commission nationale de l'informatique et des libertés (CNIL), Case C-507/17, 2019.

${ }^{14} \mathrm{Ibid}$, paras 62 and 65.

${ }^{15}$ Ibid, para 66.

${ }^{16}$ Ibid, para 59.

${ }^{17}$ Ibid, para 60. 
Australia, Hong Kong is a jurisdiction covered by the Foreign Judgments Act 1991 (Cth). Judgments rendered by Hong Kong courts can benefit from the registration procedure under the Act which is more pro-judgment creditors than the common-law enforcement proceedings. However, no regulation has been made pursuant to s5(6) of the Act in respect of non-money judgments. The Act only applies to money judgment given in civil proceedings or on a civil claim in criminal proceedings. ${ }^{18}$ Therefore, Hong Kong judgment on national security violation cannot be enforced under the Act. Moreover, public policy exception in western countries likely blocks the recognition and enforcement of Hong Kong judgments rendered under the Hong Kong Security Law. Furthermore, an Internet intermediary may seek a judgment in its home country to block the recognition and enforcement of Hong Kong judgments rendered under the Hong Kong Security Law. For example, in LICRA \& UEJFv Yahoo! Inc \& Yahoo France, Yahoo! was ordered by a French court to block French users from accessing the auction site on Yahoo.com that offered Nazi memorabilia in contravention of French law. ${ }^{19}$ Yahoo! is registered in the US. It went to a US district court and successfully obtained a judgment declaring that the French judgment was not recognizable and enforceable as they violated the First Amendment to the US Constitution. ${ }^{20}$ Although the district court judgment was reversed at the appellate level on grounds of lack of personal jurisdiction on LICRA \& UEJF and the 'ripeness' of the enforcement claim, it nevertheless demonstrates that the First Amendment to the US Constitution can potentially be used to protect US-domiciled websites from enforcing foreign judgments. ${ }^{21}$ Similarly, in Google Inc $v$ Equustek Solutions Inc, Google was required by a Canadian court to block websites violating Canadian law. ${ }^{22}$ Google, again, a company with a domicile in the US, obtained a judgment at its home court making the Canadian judgment unenforceable. ${ }^{23}$ In the Hong Kong scenario, the foreign Internet intermediary can request the court in the place of registration to issue a decision to reject recognition and enforcement of the Hong Kong judgment. Therefore, the posts are likely not to be removed. Nevertheless, the Internet intermediary may choose to voluntarily comply with the Hong Kong court decision by blocking audience from Hong Kong to access the posts. This is what Yahoo! did in LICRA \& UEJF and Google did in Equustek Solutions Inc.

\section{Conclusion}

The extra-territorial application of Hong Kong Security Law has important implications. Internet intermediaries and content providers that may be involved in publishing or developing contents allegedly violating Hong Kong Security Law should consider changing their place of registration or moving their assets outside of Hong Kong to countries that do not have an extradition treaty with Hong Kong or that may not recognize and enforce Hong Kong judgments rendered according to Hong Kong Security Law.

\footnotetext{
${ }^{18} \mathrm{~S}$ 3(1) of the Foreign Judgment Act (Cth).

${ }^{19}$ LICRA \& UEJF v Yahoo! Inc \& Yahoo France (Tribunal de Grande Instance de Paris, 20 November 2000).

${ }^{20}$ Yahoo! Inc v La Ligue Contre le Racisme et l'Antisemitisme, 169 F. Supp. 2d 1181 (N.D.Cal. 2001).

${ }^{21}$ Upon the UEJF and LICRA's appeal, the US Court of Appeals for the Ninth Circuit held that the District Court lacked jurisdiction, and it ultimately decided to rehear the case en banc and reversed the District Court's judgment, remanded the case with directions to dismiss the action on 12 January 2006. Yahoo! Inc, v. LICRA and UEJF, $433 \mathrm{~F} 3 \mathrm{~d} 1199$ ( $9^{\text {th }}$ Cir. 2006). The Supreme Court of the US denied LICRA's request to issue a certiorari on 30 May 2006. However, Yahoo! has chosen to remove the sale of Nazi memorabilia from its site entirely.

${ }^{22}$ Equustek Solutions Inc v Jack (2014) 374 DLR (4th) 537; Equustek Solutions Inc v Google Inc (2015) 386 DLR (4th) 224; see also Google Inc v Equustek Solutions Inc [2017] 1 SCR 824. Jennifer Daskal, 'Google Inc. v. Equustek Solutions Inc.' (2018) 112 American Journal of International Law 727, 727-33.

23 Google Inc v Equustek Solutions Inc., 2017 SCC 34.
} 
However, we will see more Internet intermediaries and content providers to divide their service into business that may violate Hong Kong Security Law and business that complies with the Law. Although the former type of business may migrate to other part of the world, the latter type is typically related to Mainland Chinese market and will stay in Hong Kong. Nevertheless, the risk of this business model is that Hong Kong courts may render a global injunction ordering an intermediary registered in Hong Kong to remove or de-reference contents violating Hong Kong Security Law from all its service including that for people in other jurisdictions. Advisably, Hong Kong courts should refrain from issuing such injunction and respect that other jurisdictions may have adopted different values of censorship, national security and freedom of speech. 